\title{
The "Very Long Hiccup" and the Emergence of the Army Medical Services in Malta
}

\author{
Lt Col W Bonnici \\ MRCGP, DCH, RAMC
}

\section{Armoured Field Ambulance, Gaza Barracks, Catterick Garrison, DL9 4AU}

SUMMARY: The link between the Maltese islands and the Army Medical Services was forged during the Wars of $\frac{\bar{\omega}}{\bar{N}}$ Revolutionary France, 1792 to 1802. This article looks at the two-year long blockade of the French garrison in Malta, $\overparen{\varnothing}$ Nelson's so called "very long hiccup" (1), and at the origins of the Army Medical Services in the Maltese islands.

\section{Introduction}

The Treaty of Paris, 30 May 1814, conferred the Maltese Islands to the British Crown. However, on 5 September 1800 , Great Britain had expelled the French from Malta and had become the de facto possessor of the islands. The occupation of Malta by British troops was intended to be temporary. At the Peace Treaty of Amiens, 27 March 1802, which brought the French Revolutionary Wars to an end, Britain agreed to relinquish Malta. The treaty was not implemented. The illusion of peace was shattered, and in May 1803 Britain and France resumed hostilities. Malta remained a British Protectorate. Its geographical location made it an ideal base as a depot for ordnance and medical stores, and as a staging post for troops in the Mediterranean. However, Malta did not grow sufficient food to feed its population as well as maintain a large garrison and relied on Sicily for as much as two thirds of its annual consumption of wheat and barley. This was a major drawback, for in the event of hostilities, a blockade of Malta would stop the importation of food and force the capitulation of the island.

\section{French Troops in Malta}

The French Army of the East embarked at Toulon for Egypt on 19 May 1798. It appeared off Malta on 9 June, and within three days General Napoleon Bonaparte expelled the Order of St John who had held the island since 1530, and added Malta to his conquests. Before sweeping off to Egypt on 19 June, Napoleon introduced such radical changes in the political, social and religious laws of the Maltese, that he alienated the population, Monasteries and pious foundations were suppressed, and their property confiscated.

Malta was garrisoned with 5000 troops under General Claude Henri Vaubois. On 1 August 1798, Nelson annihilated the French fleet at Aboukir, leaving Napoleon and his army stranded in Egypt. Out of 13 French ships present at Aboukir, only four escaped. The Genereux fled to Corfu, whereas the Guillaume Tell and the frigates Justice and Diane managed to reach Malta, and their crew augmented the garrison by another 2000 men.

\section{The Blockade of the French Garrison}

On 2 September 1798, the simmering discontent among the Maltese erupted in a general insurrection. In the ensuing disturbance the insurgents massacred the French garrison at the old city of Mdina. The French retreated to the safety of Valletta and the fortified towns around the Grand Harbour. o The Maltese penned them in with a series of entrenchments which extended from Fort Tigne to Fort Ricasoli. On 19 September 1798, a Portuguese squadron began a sea blockade of Malta. A month later, it was reinforced by a $\vec{\omega}$ British squadron under Captain Alexander Ball RN. The Portuguese, allies of Britain, disembarked their marines, $\stackrel{\perp}{A}$ twenty artillery men and two officers, and aided the Maltese in the conduct of the siege. Eleven gunners under the command of Lieutenant John Vivion RA landed in Malta December 1798. Prior to the arrival of the Britions Regiments on 9 December 1799, the insurgents had be supported by no fewer than 500 English and Portugues $\overrightarrow{0}$ marines (2). The French made several attempts to suppty their garrison. On 17 February 1800, the Genereux, two corvettes, and the armed store ship, Ville de Marseilles, o failed to lift the blockade. The convoy was intercepted Admiral Lord Keith, commander of the Mediterranean fleet, and 2000 troops on board the transports were taken prisoners.

\section{British Troops in Malta}

On 22 January 1799 the French captured Naples. Britain had a defensive alliance with the Kingdom of the Two Sicilies, and to protect Sicily, Lieutenant General Charles Stuart moved the 89th Foot and the 30th (Cambridgeshire) Regiment from Minorca to Messina. However, the threat to Sicily was short-lived, as a combined Austro-Russian army $\mathbb{\mathbb { D }}$ drove the French out of Northern Italy, and the French had to abandon Naples. The two British regiments in Messina thus became available for deployment to Malta. The 30th and 89th Foot, and a company of Neapolitan artillery, came $\delta$ ashore at St Paul's Bay on 10 December 1799 (Table 1). ₹ This force of about 900 men, led by Brigadier Thomas Graham, was not strong enough to storm the fortifications. Moreover, Brigadier Graham had orders from Lieutenant General H Fox, commander of the Army in the Mediterranean, to re-embark his troops and return to $\Omega$ Messina, if conditions in Malta precluded him from 0 resolving the siege (3). Unable to carry the place by an $N$ assault, Brigadier Graham could only support the insurgents with their efforts to starve out the besieged garrison. The 
Table 1. Service Return for 1 February 1800. (PRO WO 17/2117)

\begin{tabular}{lccc}
\hline Regiments & $\begin{array}{c}\text { Rank } \\
\text { \& File }\end{array}$ & Sick & $\begin{array}{c}\text { Died Since } \\
\text { 1 Jan 1800 }\end{array}$ \\
\hline Royal Artillery & 27 & 0 & 0 \\
Neapolitan Artillery & 103 & 5 & 0 \\
British Marines & 297 & 121 & 9 \\
30th Foot & 481 & 21 & 1 \\
89th Foot & 452 & 97 & 20 \\
\hline Total & $\mathbf{1 3 6 0}$ & $\mathbf{2 4 4}$ & $\mathbf{3 0}$ \\
\hline
\end{tabular}

French felt secure in one of the strongest fortresses in Europe and had enough food to sustain a long siege. During the time of the Order of St John, the island's food reserves were stored in silos within the towns and no grain was kept in the countryside lest it fell into enemy hands. Thus the insurgents found themselves short of food and famine and disease prevailed in their camp. Billets for the British troops were prepared by Lt Vivion RA, who had undertaken the task of Assistant Quartermaster General. On 11 December, the 30th Foot moved into the villages of Ghaxaq and Zejtun. The troops guarded the battery of St Roque and the advanced outpost of Zabbar. The 89th Foot occupied Gudja, Luqa, and the advanced outpost of Tarxien. This included Ta' Borg Battery in front of it and extended along the road between Tarxien and Zejtun, down to Zabbar as far as the old windmill. The British marines took up positions at Samra, Jesuits Hill Battery, and San Giuseppe. They secured the main road from Valletta to Mdina. The line from San Giuseppe to Fort Tigne was entrusted to the Maltese battalions. If overwhelmed by a French sortie, the troops were to withdraw to Ghaxaq and Zeijtun, and then to their of embarkation point at Marsaxlokk (4). The Headquarters of the British force was at Villa Bettina in the village of Gudja. $\stackrel{?}{\rightarrow}$ These positions are shown in a map drawn by Colonel $\bar{C}$ Lewis Lindenthal, an engineer on the Staff of General Fox, who arrived from Minorca on 6 December 1799 (Fig 1). A $\frac{5}{\vec{D}}$ further twenty British gunners led by Lieutenant Reynell $\stackrel{\varnothing}{\AA}$ arrived from Sicily on 28 December 1799 (5). The British क troops were reinforced by 1200 Neapolitan soldiers on 15 February 1800, and another 900 arrived in April. The Neapolitans guarded the outposts between Fort Tigne and Fort Manoel.

On 12 May 1800 , a secret expedition to support the Austrian army in Lombardy gathered at Minorca under Major General Henry Pigot. Among those assembled were the 48th (Northamptonshire) and the 35th (Dorsetshire) Regiments. General Sir Ralph Abercromby who in May 1800 succeeded General Charles Stuart as Commander inChief of the Mediterranean, joined the expedition in Minorca on 23 June. There, instructions from the Secretarp at War directed him to augment the British troops in Malt to "2500 or 3000 effective men", so as "to render the blockade more secure and to relieve the marines and $\Phi$

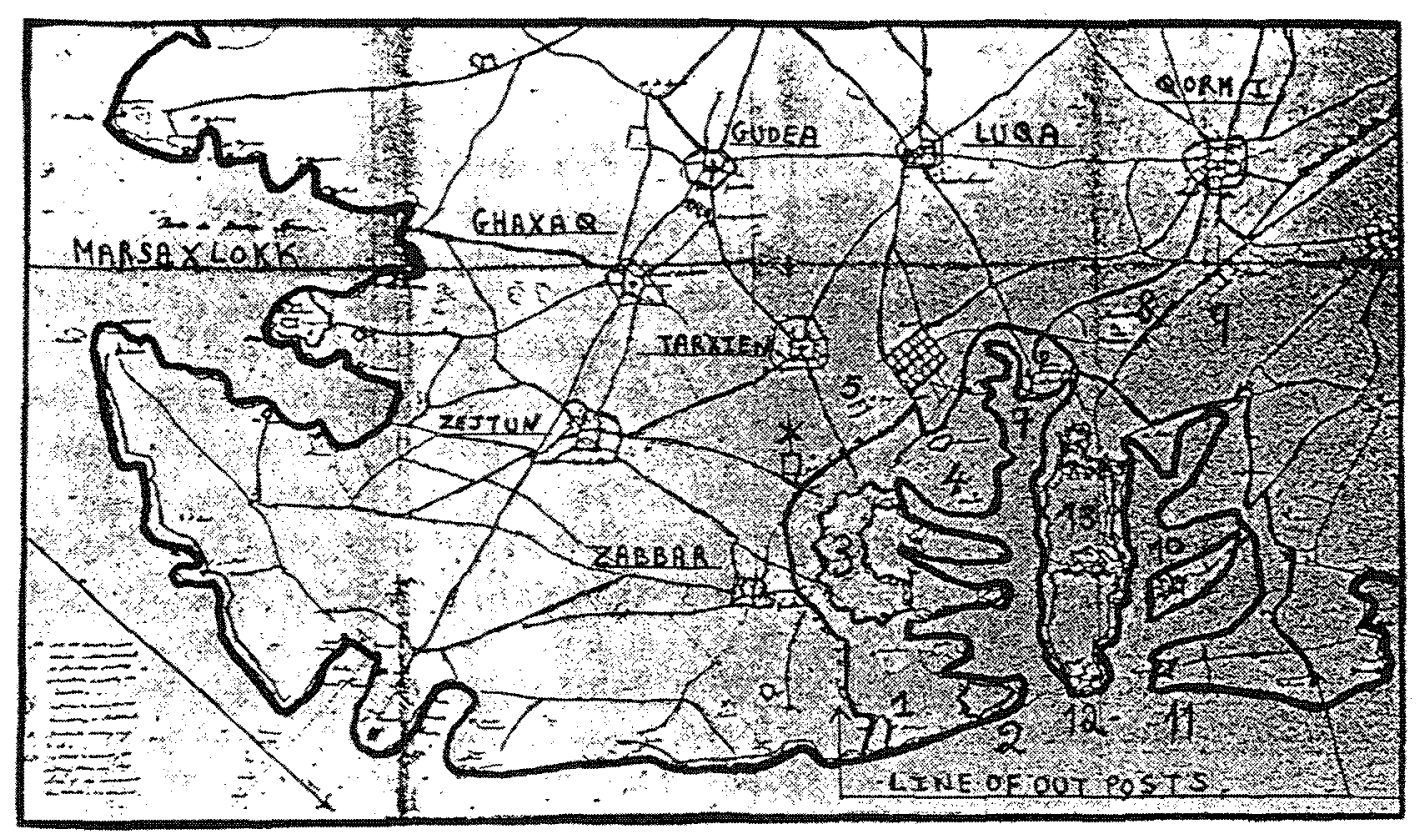

Code: 1. St Roque Bty; 2. Fort Ricasoli; 3. Cottonera; 4. Corradino; 5. Ta Borg Bty; 6. Jesuits Bty; 7. Marsa; 8. Samra Bty; 9. San Giuseppe; 10. Fort Manoel; 11. Fort Tigne; 12. Fort St Elmo; 13. Valletta.

Fig 1. Map South East Malta Showing Positions of British Outposts Around Valletta and Neighbouring Villages (PRO MPH 74, 28 December 1799 Lindenthal to Fox). 
seamen now doing duty on shore and which appear to be wanted on board the fleet" (6). The 35th was ordered from Minorca to Malta. The 48th proceeded to Leghorn. It reached Leghorn on 9 July, but before it got there, Napoleon had defeated the Austrians at Marengo and hostilities had ended. The 48th then headed for Malta and reached the island on 28 July 1800 .

Although weakened by disease and dwindling food stocks, General Vaubois refused to capitulate. General Abercromby ruled out a direct assault on the fortifications as these were considered to be too strong. An alternative plan to land British troops within the precincts of Fort St Elmo and Fort Ricasoli was also considered to be too hazardous (7). In fact, neither Lord Keith nor General Abercromby thought that Valletta would ever be forced to surrender. It was therefore decided to withdraw the troops and lift the blockade if the French had not capitulated by October 1800 (8). The strength of the British Forces in Malta on 1 October 1800 is shown in Table 2.

Table 2. Service Return for 1 October 1800. (PRO WO 17/2117)

\begin{tabular}{lccc}
\hline Regiments & $\begin{array}{c}\text { Rank } \\
\text { \& File }\end{array}$ & Sick & $\begin{array}{c}\text { Died Since } \\
\text { 1 Sep 1800 }\end{array}$ \\
\hline Royal Artillery & 114 & 15 & 3 \\
30th Foot & 442 & 67 & 5 \\
1/35th Foot & 848 & 152 & 40 \\
2/35th Foot & 907 & 89 & 7 \\
48th Foot & 581 & 89 & 20 \\
89th Foot & 414 & 77 & 3 \\
Maltese Infantry & 786 & 37 & 6 \\
Neapolitan Artillery & 122 & 19 & \\
Neapolitan Reg of & & & \\
Valde Mazzara & 646 & 52 & 4 \\
\hline Total & $\mathbf{4 8 6 0}$ & $\mathbf{5 9 7}$ & $\mathbf{8 8}$ \\
\hline
\end{tabular}

Table 3. Morbidity and Mortality of British Troops from Monthly Returns 1800. (PRO WO 17/2117).

\begin{tabular}{lcccccc}
\hline Regiments & Jan & Feb & Apr & May & Sep & Oct \\
\hline Rank \& File 30th & 480 & 481 & 478 & 467 & 447 & 442 \\
Rank \& File 89th & 471 & 452 & 438 & 437 & 417 & 414 \\
Rank \& File 1/35th & - & - & - & - & 884 & 848 \\
Rank \& File 2/35th & - & - & - & - & 915 & 907 \\
Rank \& File 48th & - & - & - & - & 601 & 581 \\
Sick 30th & 11 & 21 & 42 & 26 & 78 & 67 \\
Sick 89th & 20 & 97 & 78 & 35 & 72 & 77 \\
Sick 1/35th & - & - & - & - & 176 & 152 \\
Sick 2/35th & - & - & - & - & 96 & 89 \\
Sick 48th & - & - & - & - & 72 & 89 \\
Dead 30th & 2 & 1 & 0 & 3 & 5 & 5 \\
Dead 89th & 1 & 20 & 3 & 0 & 11 & 3 \\
Dead 1/35th & - & - & - & - & 39 & 40 \\
Dead 2/35th & - & - & - & - & 3 & 7 \\
Dead 48th & - & - & - & - & 11 & 20
\end{tabular}

Morbidity and Mortality among British and French Troops

A memorial of the Maltese deputies dated 22 October 1801 states that out of a population of around 130,000, "the $\Omega$ Maltese lost above 20,000 souls, whereas the British troops 응 had not one soldier killed by the enemy" (9). This implies of that the mortality and morbidity among British troops as shown in Table 3 and in Figures 2 and 3 were entirely due $\stackrel{0}{?}$. to disease. It is difficult to ascertain the exact cause of the large number of sick among the 35th and 48th Regiments, but overcrowding on board the transports must have had a $\frac{\mathrm{c}}{\overrightarrow{\mathrm{C}}}$ contributory effect. In his journal of the Secret Expedition $\mathbb{\Phi}$ Lieutenant Aeneas Anderson, 40th Regiment, describes कै how no less than 1300 men and sixty officers were packed $\overrightarrow{0}$ on board one ship which had no accommodation whatsoever. The scarcity of water, the insanitary conditions, $\vec{\omega}$ and the stifling Mediterranean summer "subjected the troops to such distressing inconvenience, the heat of the weather would infallibly have carried off one third of thern" (10). Febrile illness accounted for much of the morbidity. $\vec{A}$ During March and April 1799, a malignant fever, or typhus fever, struck the Maltese irregulars. All the Portuguese and $N$ Neapolitan troops fell ill. Of the eleven British artillery men $\vec{A}$ who had disembarked from the Bomb ketch Stromboli in December 1798, two died of fever, and three becant dangerously ill. The malignant fever spread to Capta解 Ball's ship, HMS Alexander, "from having freque ht communications with the inhabitants, and the sick lit suddenly increased from 5 to 27 , of which two only died arid $\overrightarrow{8}$ the rest recovered" (11). The seamen with the slightegt.

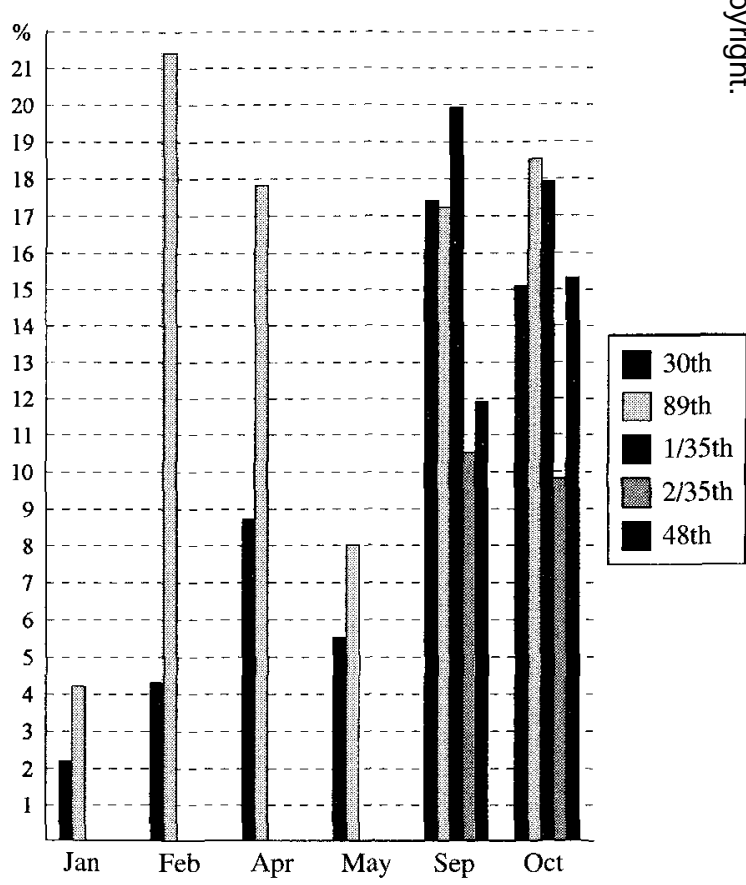

Fig 2. Morbidity Expressed as a Percentage of Total Rank and File January to October 1800. 


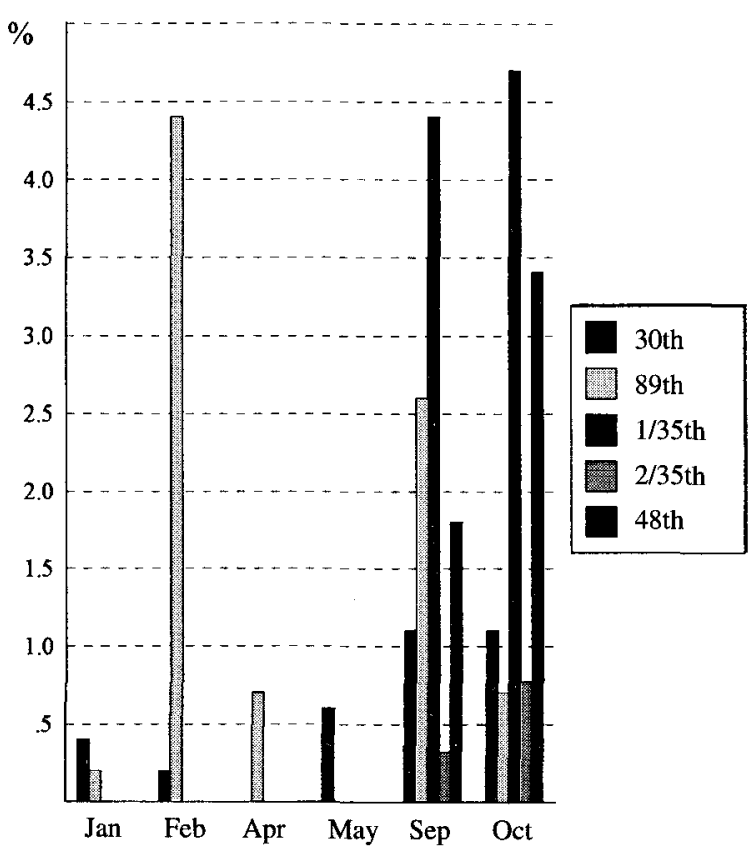

Fig 3. Mortality Expressed as a Percentage of Total Rank and File January to October 1800.

fever were conveyed to a house located in "an airy situation" which aided their recovery. Typhus fever also appeared on board the captured French ships, the Genereux and Ville de Marseilles. Those prisoners "infected with a bad fever were sent to Comino", an uninhabited isle to the North of Malta, where "a sufficient quantity of clothes and provisions were first landed on one side of the isle, and the prisoners on the other side, who all were made to strip and wash, first in the sea, then with vinegar, and then dress themselves in their new clothing" (12).

Another fever prevalent on the island was intermittent fever, or malaria. This is transmitted by the bite of the Anopheles mosquito, a species of which, Anopheles maculipennis, bred in the stagnant waters of Marsa, Luqa and the low lying village of Qormi. On 16 December 1799 , Brigadier Graham informed Lord Keith that the 89th and the marines were suffering from the "country fever ( $a$ kind of intermittent), many of these are convalescent but on the least irregularity or fatigue they relapse and die" (13). The fever was attributed to the men sleeping on stone or earth floors, so that boards of deal were requested from Sicily for them to sleep on. By 1 January 1800 , eighty-five out of the 400 marines were sick. The following month, 121 marines were ill, and thirteen had died. On 23 July Lord Keith reported that out of all the marines landed in Malta all but 178 were incapacitated with fever (14). Brigadier Graham was in no doubt that the fever originated "from the bad air of the marsh at the head of the harbour, though from several instances there is reason to consider it likewise infectious" (15). It spread so rapidly among the 89th at Luqa, that the troops were relieved of night duty and moved to Ghaxaq.
Cinchona or Peruvian bark, the active ingredient of which is quinine, proved effective against the fever. Byz 16 December 1799, Peruvian Bark had completelyळ run out, and "all other medicines were very deficient" (13).

The French soldiers, weakened by malnutrition, fell prey⿳⺈ to the same febrile illnesses as their British counterparts. Dysentery was rife among them. A heavy infestation by the ? round worm Ascaris lumbricoides caused colic and? intestinal obstruction. During the winter of 1799, the French $\frac{\bar{\sigma}}{\overline{0}}$ hospitals contained more than 600 soldiers, the greater part $\overrightarrow{\mathbb{D}}_{\overrightarrow{0}}$ of whom had scurvy. Vinegar was considered to be an effective anti-scorbutic and wine was set aside for such purpose. However, without fresh rations, scurvy progressed $\vec{O}$ unchecked and 555 soldiers died in the first year of the siege (16). The French also suffered from night blindness caused $\vec{\omega}$ by a deficiency of Vitamin A. General Vaubois reported that? "as soon as the day is over these malcontent are in a state of absolute blindness and they do not recover their sighto until day break" (17). During the second year of the siege $\vec{A}$ (September 1799 to August 1800) the French lost anotherct 170 soldiers from disease (16).

The Army Medical Services in Malta
In 1799 the Army Medical Service was run by a Board of three members consisting of the Physician General, the Surgeon General, and the Inspector of Regimeng Hospitals. The Army Medical Board kept in contact wifm the various foreign expeditions through its Inspector ${ }_{f} \vec{\varrho}$ Hospitals. Dr James Franck, a Physician to the Forcgs. since 1794, was the Inspector of Hospitals for Mediterranean. He was appointed on 4 April 1800 , on tese recommendation of General Charles Stuart. His salary wiᄍ 30 shillings a day (18). Dr Franck was based at Port Mahon in Minorca. An Assistant Inspector of Hospitals, Alexander $\stackrel{\square}{\square}$ Jamieson, accompanied the troops to Malta. Mr Jamieson $\overrightarrow{\vec{P}}$ was the head of the Medical Staff Officers on the island. He was responsible for setting up the General Hospital. At his request, hospital stores, Peruvian Bark and a surgeon'so mate were sent to Malta from Minorca. On 1 February 1800, a General Hospital was opened at Zejtun in the country house of Count Agostino Formosa de Fremeaux, the Consul for Holland and Prussia (19). The hospital also admitted the sick of the Neapolitan Artillery, who were@ without a surgeon. Brigadier Graham had some misgivings? about the General Hospital: "The want of regular and well supplied markets in the island makes it impossible for the. hospital to be put on the footing directed by the King's Regulations" he wrote "and the men cannot be provided otherwise than by drawing rations from the Assistant $\mathrm{O}$ Commissary General" (15). One of the civilian hospitals at Rabat, Saura Hospital, was also used by the British. Soldiers dying at this hospital were buried in an adjacent field owned by Rosa Cutajar (20), who petitioned for, and was granted a yearly pension of 7 scudi (58 pence) in compensation for the loss of her property (21). Drew Jamieson became Physician to the General Hospital at? Zejtun. The Medical Staff Officers attached to the Generako 
Hospital on 1 September 1800 were:

Mr Alexander Jamieson

Mr Edward Tegart

Mr Joseph Gunson

Mr W May

\section{Mr Norman and Mr Anderson Hospital Mates}

Purveyors and Apothecaries were selected from experienced assistant surgeons or senior hospital mates. They were appointed to the staff of general hospitals by the Inspector of Regimental Hospitals. Hospital Mate $\mathrm{Mr}$ Joseph Gunson was appointed Deputy Purveyor to the General Hospital by Brigadier Graham on 22 February 1800. His service return, however, records the date of his promotion as 8 April (22). The Purveyor ensured that the hospital was furnished with every item required, and provided the diets to the patients as prescribed by the physician. In addition he kept weekly accounts of provisions and expenditure and made requisition for stores to the Surgeon-General. The Regiments of Foot had a Surgeon, and a Surgeon's Mate. The Surgeon was a commissioned officer appointed by the Surgeon General. The Surgeon's Mate was a warrant officer who had his warrant signed by the colonel of the regiment. From 30 November 1796, Surgeon's Mates became known as Assistant Surgeons and were appointed by commission.

The regimental surgeon administered the regimental hospital. This was either collocated with the General Hospital, or set up in a large rented house. Thus, on 17 July 1800 , the expected arrival of a large number of artillery men, led Lt Vivion to requisition a large house at Zejtun to serve as the regimental hospital for the British Artillery (19). Mr Edward Tegart was the regimental surgeon of the 30th Foot. He was commissioned on 10 December 1794, and was promoted staff surgeon to the general hospital on 4 April 1800. Staff Surgeon Tegart was the senior surgeon in Malta until 24 September 1802 (22). Like many other staff officers he had been discharged on half pay at the end of the French Revolutionary Wars, but was recalled to the service on 22 July 1803, following the outbreak of the Napoleonic Wars. The vacancy left in the 30th Foot by the promotion of Mr Tegart was filled by Mr Ebenezer Brown, assistant surgeon of the 79th Foot (23). Mr John Price was the assistant surgeon of the 30th Foot. Since 15 May 1796, Mr Price had served as the Surgeon's mate of the 30th Foot, and was commissioned assistant surgeon on 1 May 1797. While in Malta, he was detached from his regiment for duty at the general hospital, and also acted as assistant surgeon to the Royal Artillery. The surgeons and assistant surgeons of the other British regiments were:

89th Foot: Surgeon - Mr Henry Reed; Assistant Surgeon Mr P Campbell.

48th Foot: Surgeon - Mr Henry (William) Grasett;
Assistant Surgeon Mr William Hill.

35th Foot: Surgeons - Mr Jonathan Cotgrave and Mr Alexander Thom; Assistant Surgeons - Alexander (James) Baxter, William Robertson and George Peach.

\section{Epilogue}

On 5 September 1800 , General Vaubois bowed to the inevitable and surrendered his starving troops to Major General Henry Pigot, who had accompanied the 35th Foot to Malta. The Maltese Islands were taken under the protection of Great Britain. Subsequently the 30th and 89th Regiments embarked with the Army for Egypt on 17 December 1800. Brigadier Graham obtained 6 months leave of absence and returned to England on 15 September. Thus came into effect the British presence in Malta, which was to last until 31 March 1979.

\section{REFERENCES}

Documents cited at Public Record Office (PRO):

1. PRO: WO 1/291, 14 Dec 1799. Nelson to Fox.

2. WO $1 / 296,16$ Oct 1799. St Clair Erskine to Dundas.

3. WO $1 / 291,12$ Nov 1799 . Stewart to Graham.

4. WO 1/291, 28 Dec 1799. Graham to Fox.

5. WO 1/291, 28 Dec 1799. Lindenthal to Fox.

6. WO $1 / 298,5$ May 1800 . Dundas to Abercromby.

7. WO $1 / 344,21$ July 1800 . Minutes of conversation a HQ Gudea.

8. CO 158/12, 10 Sept 1806. Ball's narrative of service in Maita.

9. CO 158/13, 23 June 1807. Letters of Mr Eton.

10. ANDERSON A. A journal of the forces which sailed from the Downs in April 1800 on a secret expedition London 1802.

11. Hardman W. Ball to Nelson, 31 Mar 1799 in A history of Malta during the period of the French and British occupations 1798-1815. Longmans \& Co 1909.

12. CO 158/23, 7 Aug 1813. Aldridge to Bathurst.

13. WO 1/291, 16 Dec 1799. Graham to Keith.

14. HARDMAN W. A history of Malta during the period of the French and British occupations 1798-1815. Longmans \& Co 1909.

15. WO 1/291, 1 Feb 1800. Graham to Fox.

16. BoISGELIN LouIS De. Ancient and Modern Malta Volume 3. Malta 1899.

17. VAuBoIS H. Journal of the siege of Malta. In Hardman W A history of Malta.

18. WO 4/319, 4 June 1800 War Office to Fox.

19. MIFSUD A. Origine della Sovranita Inglese su Malta. Malta 1907.

20. CO 158/3, 27 Dec 1801. Villettes to Cameron.

21. CO $158 / 25$, f355 Oct 1814 . Pensions payable by the Civil Government.

22. WO 25/3909, Returns of service.

23. WO 4/319, 4 Apr 1800 . War Office to Fox. 